\title{
SEED MORPHOLOGY OF TWO DISTINCT EUROPEAN SPECIES OF ERICA L. (ERICACEAE)
}

\author{
Jaime FAGÚNDEZ* \& Jesús IZCO \\ Departamento de Botánica, Facultad de Farmacia, Universidad de Santiago de Compostela, 15782 \\ Santiago de Compostela, A Coruña, Spain \\ *Corresponding author: jaime.fagundez@usc.es
}

Recibido el 21 de mayo de 2008, aceptado para su publicación el 30 de junio de 2008 Publicado "on line" en septiembre de 2008

\begin{abstract}
Seed morphology of two distinct european species of Erica L. (Ericaceae). Erica spiculifolia is a distinct species within the genus Erica, considered by some authors as part of a monospecific genus: Bruckenthalia. The second species studied, E. umbellata, is the only European species of section Pyronium. Seed morphology of the two species was studied by means of SEM techniques. Seeds from different populations were used. Characters concerning size and shape of seeds, primary and secondary ornamentation were observed and measured. The seeds of E. spiculifolia are close to those of other species within the genus, supporting the inclusion in Erica. E. umbellata seeds have some exclusive characters within the European species of the genus: a verrucate secondary ornamentation and surface cells with "omega type" cell boundaries. The systematics of genus Erica is still unresolved, and the taxonomic position of these species has to be clarified. As found in previous studies, seed characters provide useful taxonomic characters that should be used in the interpretation of the taxonomic position of these species within Erica.
\end{abstract}

Key words. Erica, Ericaceae, seed morphology, SEM, testa sculpture, taxonomy.

RESUMEN. Morfología de las semillas de dos especies europeas de Erica L. (Ericaceae). Erica spiculifolia es una especie con características únicas dentro del género Erica en Europa, considerada por algunos autores como perteneciente al género monoespecífico Bruckenthalia. La segunda especie estudiada, E. umbellata, es la única especie de la sección Pyronium dentro del núcleo norte del género. Se estudia la morfología de las semillas mediante la fotografía de microscopía electrónica. Se miden semillas de diferentes poblaciones de cada especie. Se estudian y miden diversos caracteres del tamaño y la forma de las semillas, la ornamentación primaria y secundaria. Las semillas de E. spiculifolia coinciden en la mayor parte de los caracteres con otras especies del género, lo que apoya su pertenencia a Erica. Las semillas de E. umbellata presentan algunos caracteres exclusivos que permiten diferenciarla de otras especies europeas del género: una ornamentación secundaria verrucosa y las uniones entre las células de la testa de "tipo omega". La taxonomía del género Erica no está aún resuelta, y la posición sistemática de estas especies debe clarificarse. Como se desprende de éste y otros estudios publicados, la morfología de las semillas aportan caracteres de diagnóstico que deben utilizarse para una correcta interpretación de las relaciones taxonómicas dentro del género.

Palabras clave. Erica, Ericaceae, morfología de las semillas, M.E.B., ornamentación de la testa, taxonomía 


\section{INTRODUCTION}

Erica L. (Ericoideae, Ericaceae) is a large genus of more than 800 species with a wide distribution from Northern Europe to South Africa (Oliver, 2000). Systematics of this genus is still unresolved, because even though a high morphological variation is found for a large set of characters, researchers have failed to establish a consistent classification that would include all this data. The position of the two species included here are not clear and both have been isolated in previous classification attempts.

Bruckenthalia was a monotypic genus described by Reichenbach (1831) for its only species B. spiculifolia (Salisb.) Reichenb. This genus was characterized by the absence of bracteoles, the partially fused sepals and a distinct caryology type (Webb, 1972; Stevens, 1978; Oliver, 1989, 1996, 2000). Recently, Oliver $(1989,2000)$ claims for the inclusion of this species in Erica as was originally described by Salisbury (1802).
This proposal is based mostly in the existence of african Erica species with fused sepals and bracteoles absent because these are substituing two of the sepals. $E$. spiculifolia occurs in mountain shurblands on acid soils, from 1400 to 2500 metres (Barbero et al., 1975; Browicz, 1983). It is found in the Balkans, Transylvania mountains in Romania and some isolated populations in northern Turkey (Stevens, 1978; Browicz, 1983; fig. 1).

Erica sect. Pyronium Salisb. ex Benth. is formed by one European species, $E$. umbellata L. and about twenty species from South Africa (Schuman and Kirsten, 1992). Although this classification is doubtful, $E$. umbellata is a distinct species within the European group, characterized by its inflorescence with terminal whorls of flowers at the end of secondary branches, urceolate corolla and exerted anthers (Bentham, 1839; Hansen, 1950; Bayer, 1993). A few varieties have been described and one raised to subspecies: E. umbellata subsp. major (Coss. ex Willk.) Pinto da Silva

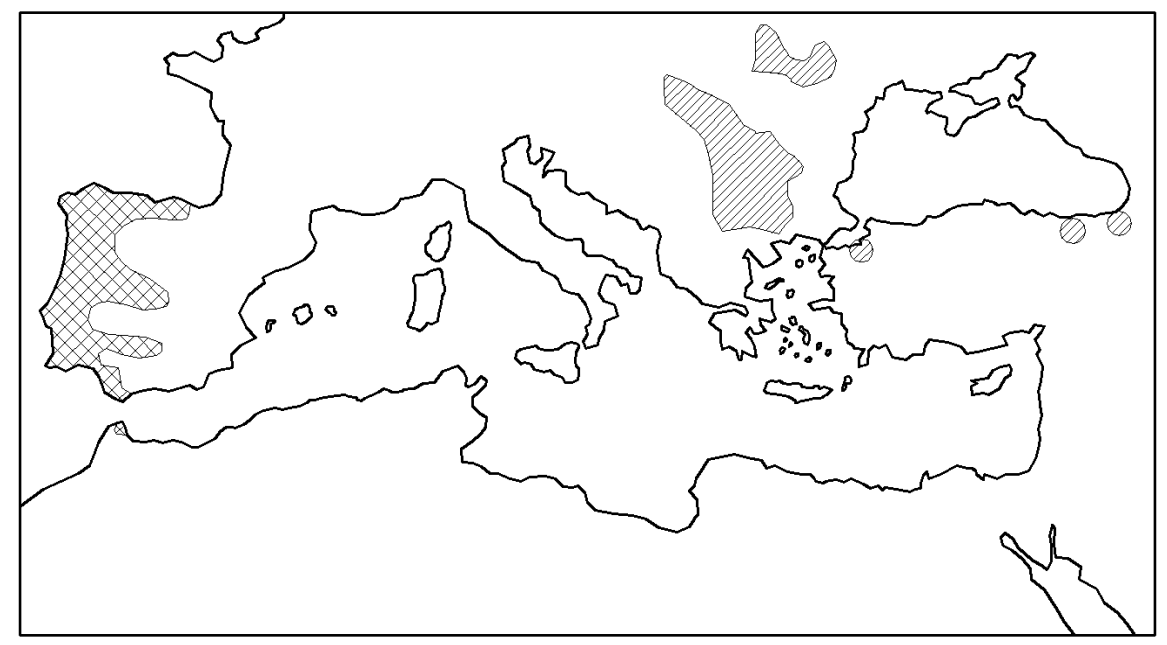

Figure 1. Approximate geographical distribution of E. spiculifolia (straight lines) and E. umbellata (crossed lines). Distribución aproximada de E. spiculifolia (rayado) y E. umbellata (cruzado). 
\& Teles, with larger corollas and less exerted anthers (Pinto da Silva \& Teles, 1971). Some other varieties such as var. subcampanulata Benth.ex DC., var. anandra Lange and var. filiformis Merino have been described (Bentham, 1839; Willkomm, 1870; Colmeiro, 1887; Benito, 1948; Hansen, 1950; Bayer, 1993) but with low taxonomic value. This species occurs in degradated shrublands on acid soils, in the western half of the Iberian Peninsula and north Morocco (Benito, 1948; Hansen, 1950; Webb \& Rix, 1972; Bayer, 1993; Díaz, 1998; fig. 1).

Seed morphology has recently been used as an aid to systematics in Erica (Fagúndez \& Izco, 2003, 2008) or its related genera Calluna (Fagúndez \& Izco, 2004a) and Daboecia (Fagúndez \& Izco 2004b). In this study, seed morphology was analyzed with the purpose of the establishment of taxonomic relationships with the other European Erica species. The systematics of the genus should be revised as Bentham's (1839) classification is poorly supported. The position of these two distinct species is still uncertain and more taxonomic characters as those found in seed morphology will be useful to clarify it.

\section{MATERIALS AND METHODS}

Seeds were obtained from seedbanks, field surveys or commercial (tab. 1). Seeds collected in the field were dried in a drying chamber using silica-gel and put into glass tubes with a certain amount of silica-gel with a colour component to detect possible humification. These tubes are then stored in a $4^{\circ} \mathrm{C}$ chamber. Seeds might be used for different studies or long time preservation (Fagúndez \& Izco 2003, 2004a, 2004b, 2008).

When available, 25 to 30 seeds were measured for each population. Seeds were measured with a binocular scope connected to a computer, images were captured and treated with UTHSCSA Image tool (San Antonio, Texas 1997). Characters measured were area (a), perimeter (p), major axis length $(\mathrm{M})$, minor axis length $(\mathrm{m})$, elongation $(\mathrm{M} / \mathrm{m})$ and sinuosity $\left(4 \pi \mathrm{a} / \mathrm{p}^{2}\right)$. Mean and standard deviation was calculated for each population. Weight of 100 seeds was measured for some populations only of $E$. umbellata. A Münsell colour chart for soils was used for colour determination.

For SEM pictures, 5-10 dry seeds from

\begin{tabular}{llll}
\hline Population & Locality & Date & \multicolumn{1}{c}{ From } \\
\hline spi355 & unknown & 2005 & Comercial \\
spi356 & unknown & 2005 & Comercial \\
spi376 & RUMANIA: Mt. Bucegi & 2005 & C. D. Bita-Nicolae \\
spi390 & GREECE: Makedonia & 1999 & R.B.G. Kew Seedbank \\
umb33 & SPAIN: A Coruña, Ames & 1998 & J. Fagúndez SANT 41449 \\
umb68 & SPAIN: Pontevedra, Faro & 1999 & J. Fagúndez SANT 41462 \\
umb74 & SPAIN: Lugo, Quiroga & 1999 & J. Fagúndez SANT 41463 \\
umb81 & SPAIN: Huelva, Andévalo & 1999 & J. Fagúndez \& D. Reyes SANT 41475 \\
umb141 & SPAIN: Pontevedra, Oia & 1999 & J. Fagúndez \& A. Aguilar \\
umb264 & PORTUGAL: Algarve, Alportel & 2000 & J. B. Tapada da Ajuda \\
umb278 & PORTUGAL: Beira Litoral, Buçaco & 2002 & J. B. Tapada da Ajuda \\
\hline
\end{tabular}

Table 1. Data of studied populations. Poblaciones estudiadas. 
five populations were mounted on metal stubs using double-sided adhesive tape and gold-coated. Pictures were taken of whole seeds and of specific details for three seeds from each population. Three testa cells were randomly chosen and measures taken in the same way as for the whole seed.

Nomenclature used is that of Berggren (1981) for shape description and Barthlott $(1981,1984)$ for the ornamentation.

\section{RESULTS}

Values of size and shape of seeds are summarized in table 2. Both species have seeds around $0.5 \mathrm{~mm}$, minor axis of $0.3 \mathrm{~mm}$ and elongation close to 1.75 (axis ratio 2:1 to $3: 2$ ). Shape of the seeds is variable, either simmetrycal from hilum, ellipsoid or oblong, or with hilum laterally displaced, curved to kidney-shape, mostly in E. spiculifolia (fig. $2 \mathrm{E})$. In this species, a lateral wing is sometimes observed (fig. 2 A).

The primary ornamentation is reticulate in both species, with elongated surface cells. E. spiculifolia has prominent outer anticlinal cell walls, mostly totally fused, while cell boundaries are channelled in E. umbellata. This species has strongly sinuate cell margins described as "omega type" (Barthlott, 1981, 1984). The secondary sculpture of E. umbellata has surface cells covered with micropapillae in both outer anticlinal and outer periclinal walls (fig. 3 D). In E. spiculifolia, surface is rugulose, with no clear pattern (fig. $2 \mathrm{~B}, \mathrm{D}$ and F).

The interpopulations variability for the meassured characters is high (tab. 2) for both species, but mostly for $E$. umbellata with populations that almost do not overlap, as populations "umb 33" and "umb 278". Weight of 100 seeds was $1.9 \mathrm{mg}$ for "umb 33 " but 2.5 to 2.8 for the other populations. Colour of mature seeds was dark to very dark brown in E. umbellata, while E. spiculifolia has lighter seeds, reddish brown or dark reddish brown.

No seed characters would support the existence of E. umbellata subsp. major, that would eventually correspond to populations "umb81" and "umb264". These populations are similar to all the rest according to the characters observed.

\begin{tabular}{|c|c|c|c|c|c|c|c|}
\hline Population & $\mathbf{N}$ & Area & Perimeter & Main axis & Minor axis & Elongation & Sinuosity \\
\hline spi355 & 29 & $0.1 \pm 0.01$ & $1.32 \pm 0.06$ & $0.49 \pm 0.03$ & $0.26 \pm 0.02$ & $1.87 \pm 0.18$ & $0.72 \pm 0.04$ \\
\hline spi356 & 25 & $0.12 \pm 0.02$ & $1.44 \pm 0.08$ & $0.53 \pm 0.04$ & $0.3 \pm 0.03$ & $1.78 \pm 0.18$ & $0.74 \pm 0.03$ \\
\hline spi376 & 13 & $0.11 \pm 0.02$ & $1.37 \pm 0.09$ & $0.51 \pm 0.03$ & $0.29 \pm 0.03$ & $1.75 \pm 0.17$ & $0.73 \pm 0.05$ \\
\hline spi390 & 9 & $0.12 \pm 0.01$ & $1.45 \pm 0.05$ & $0.53 \pm 0.02$ & $0.3 \pm 0.02$ & $1.8 \pm 0.13$ & $0.72 \pm 0.05$ \\
\hline Total E. spiculifolia & 76 & $0.11 \pm 0.02$ & $1.38 \pm 0.09$ & $0.51 \pm 0.04$ & $0.28 \pm 0.03$ & $1.81 \pm 0.18$ & $0.73 \pm 0.04$ \\
\hline umb33 & 25 & $0.11 \pm 0.02$ & $1.46 \pm 0.17$ & $0.49 \pm 0.04$ & $0.3 \pm 0.02$ & $0.68 \pm 0.11$ & $1.63 \pm 0.14$ \\
\hline umb68 & 30 & $0.14 \pm 0.01$ & $1.59 \pm 0.11$ & $0.57 \pm 0.05$ & $0.31 \pm 0.03$ & $0.69 \pm 0.07$ & $1.88 \pm 0.3$ \\
\hline umb74 & 31 & $0.15 \pm 0.02$ & $1.68 \pm 0.13$ & $0.56 \pm 0.05$ & $0.33 \pm 0.03$ & $0.65 \pm 0.05$ & $1.72 \pm 0.16$ \\
\hline umb81 & 31 & $0.14 \pm 0.02$ & $1.61 \pm 0.17$ & $0.56 \pm 0.06$ & $0.34 \pm 0.03$ & $0.74 \pm 0.06$ & $1.64 \pm 0.2$ \\
\hline umb141 & 24 & $0.15 \pm 0.01$ & $1.61 \pm 0.09$ & $0.57 \pm 0.04$ & $0.33 \pm 0.03$ & $0.71 \pm 0.05$ & $1.75 \pm 0.18$ \\
\hline umb264 & 28 & $0.14 \pm 0.02$ & $1.52 \pm 0.09$ & $0.55 \pm 0.03$ & $0.32 \pm 0.03$ & $0.76 \pm 0.04$ & $1.73 \pm 0.16$ \\
\hline umb278 & 32 & $0.19 \pm 0.02$ & $1.78 \pm 0.09$ & $0.64 \pm 0.04$ & $0.38 \pm 0.03$ & $0.76 \pm 0.03$ & $1.72 \pm 0.15$ \\
\hline Total E. umbellata & 201 & $0.15 \pm 0.03$ & $1.61 \pm 0.16$ & $0.56 \pm 0.06$ & $0.33 \pm 0.04$ & $1.72 \pm 0.21$ & $\mathbf{0 . 7 1} \pm \mathbf{0 . 0 7}$ \\
\hline
\end{tabular}

Table 2. Mean \pm standard deviation of seed characters. All values in $\mathrm{mm}$ except for area $\left(\mathrm{mm}^{2}\right)$, elongation and sinuosity. Media \pm desviación típica de los caracteres seminales. Todos los valores en $\mathrm{mm}$ excepto area $\left(\mathrm{mm}^{2}\right)$, elongación y sinuosidad. 

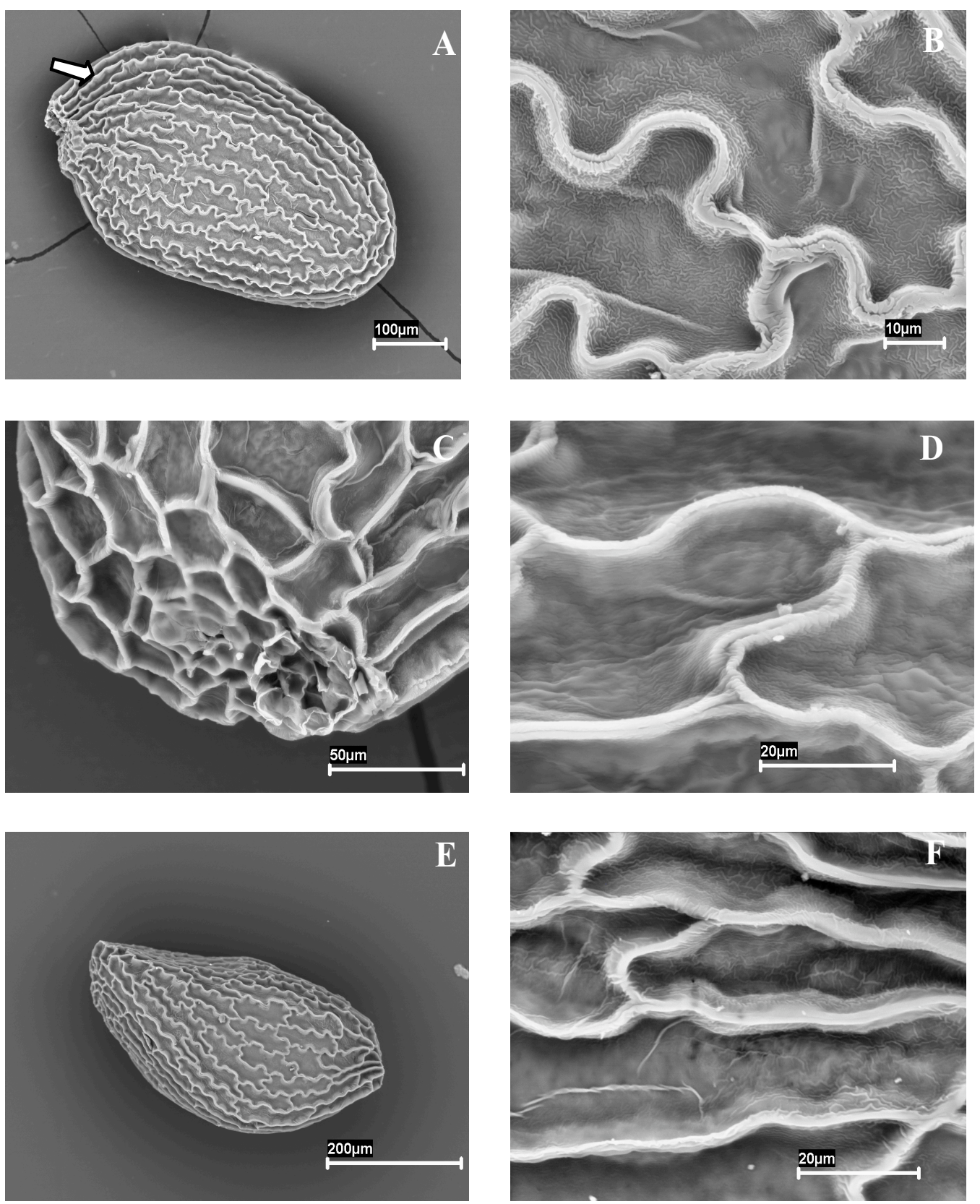

Figure 2. SEM pictures of the seeds of E. spiculifolia. A and B: spi390, C and D: spi355, E: spi356, F: spi376. A: whole seed, the winged side is pointed. B: detail of the secondary sculpture. C: detail of hilum region. D and F: detail of surface cells. E: whole seed. Fotografías de M.E.B. de las semillas de E. spiculifolia. A y B: spi390, $C$ and D: spi355, E: spi356, F: spi376. A: semilla completa. Se señala el ala lateral. $B$ : detalle de la ornamentación secundaria. C: detalle de la región hilar. D y $F$ : detale de las células de la testa. E: semilla completa. 

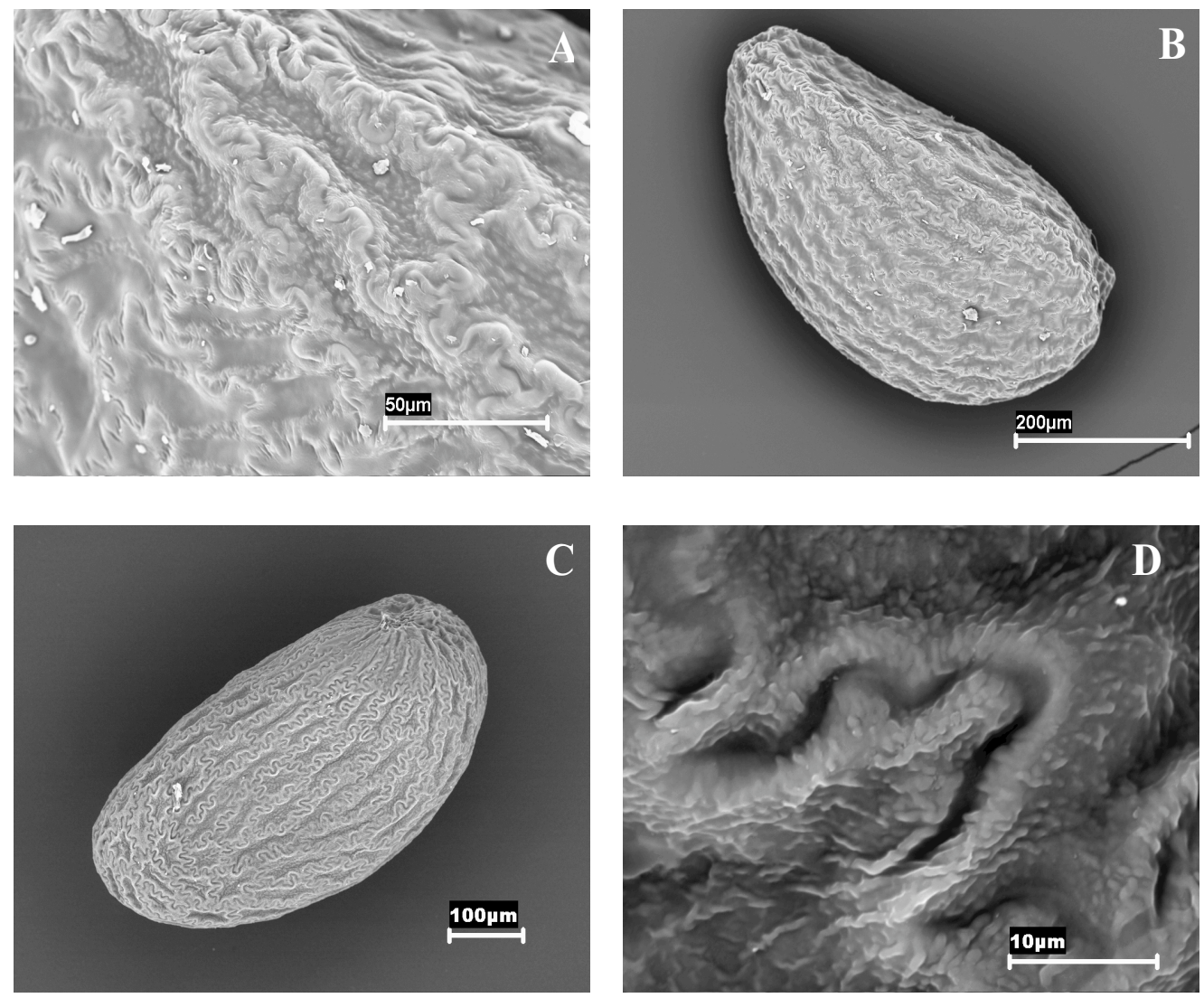

Figure 3. SEM pictures of E. umbellata. A and B: umb264, C: umb68, D: umb81. A: detail of elongated testa cells with «omega type» cell boundaries. B and $\mathbf{C}$ : whole seed. D: detail of channelled cell boundaries and surface of outer anticlinal and outer periclinal cell walls, with micropapillae. Fotografías de M.E.B. de E. umbellata. A y B: umb264, C: umb68, D:umb81. A: detalle de las células alargadas de la testa con uniones intercelulares de «tipo omega». B y C: semilla completa. D: detalle de las uniones intercelulares acanaladas y de las paredes anticlinales y perclinales externas de las células de la testa, con micropapilas.

\section{Seed description}

\section{Erica spiculifolia Salisb.}

Seeds reddish brown to dark reddish brown. Shape ellipsoid or kidney-shape. Outline elliptic or curved on the hilum region and apiculated on the distal end. Simmetrycal from hilum or this displaced to one side. Cross section flat, sometimes with a lateral wing. $0.45-0.55 \mathrm{~mm}$ long. 0.25-0.35 mm wide. Axis ratio $2: 1$ to $3: 2$. Appendages absent. Primary ornamentation reticulated, with large cells in the direction of the main axis. 6-10 cells in main axis, elongated but gradually isodiametric towards the polar areas. Cells 100-150 $\mu \mathrm{m}$ long $20 \mu \mathrm{m}$ wide, with sinuate margins. Outer anticlinal walls prominent, continued by the outer periclinal walls, these smooth or continuing the ornamentation of the outer periclinal walls, 
these rugulate. Cell boundaries anastomosing or rarely partially anastomosing.

\section{Erica umbellata L.}

Seeds dark to very dark reddish brown. Weight of 100 seeds 2-3 mg. Seed shape variable, ovate or curved, sometimes almost kidney-shape, outline with an oval or oblong base and elliptic apex, cross section elliptic with second axis significantly larger than third axis. 0.45-0.6 mm long. 0.3-0.35 mm wide. Appendages absent. Terminal hilum displaced to one side, sometimes protruding. Primary ornamentation irregularly reticulate, formed by cells of 100-150 $\mu \mathrm{m}$ long 50-100 $\mu \mathrm{m}$ wide, isodiametric towards the polar areas. 8-12 cells in main axis. Very sinuate cell margins, imbricate, "omega type". Outer anticlinal walls thick, continued by the outer periclinal walls. Secondary ornamentation strongly verrucate. Cell boundaries channelled, with ocasional fusion points.

\section{DISCUSSION}

\section{Bruckenthalia or Erica}

Seeds of E. spiculifolia have been studied by Wilson et al. (1973) for the purpose of fossil identification, described as of 0.53-0.61 mm, reticulate with elongated surface cells and curve to sinuate, partially or totally divided cell boundaries. Its seeds are also considered similar to those of $E$. lusitanica. Our results mostly agree with this description, but no similarities were found with E. lusitanica seeds, which are smaller, rounder and with isodiametric surface cells (unpub. results).

The taxonomic value of genus Bruckenthalia has been strongly discussed and it is now considered as part of Erica (Oliver, 1989, 1996, 2000; Kron et al., 2002; Nelson 2007). Abscence of bracteoles is shared with some African Erica species, and
European species such as E. scoparia also have a fused calyx. However, the caryology type, the distinct syninflorescence type and other characters results in E. spiculifolia as a very distinct species within the northern nucleus of the genus. We have also observed some original characters in the study of herbarium material, such as occasionally fused stamen filaments at its half length, another exclusive character for the northern species.

Seed morphology has differences and similarities with the other european Erica species. The presence of winged seeds, result of the embryo lateral position, is found in $E$. spiculifolia and E. arborea. Shape of the seeds is the most variable of the observed characters, as sometimes seeds are curved and apiculated as found in E. terminalis or E. maderensis (Fagúndez \& Izco, 2008), but sometimes regular, symmetrical, elliptic or oblong in its outline. Surface cell pattern is similar to the E. scoparia type (Fagúndez \& Izco, 2003), with elongated cells, sinuate margins and cell boundaries anastomosing. None of these characters are conclusive about the systematic affinities of these species, although it seems that E. arborea and E. scoparia are the most likely to be the closest species according to seed morphology.

A recent study on the phylogenetic relationships of the African and European Erica species based on chloroplast and nuclear DNA (McGuire \& Kron, 2005) resulted in E. spiculifolia as a sister species of the rest. This would suggest that seed characters such as winged seeds or a reticulate ornamentation could be primitive states within Erica.

\section{Erica umbellata and sect. Pyronium}

The E. umbellata seeds have been analyzed also for fossil studies by Huckerby et al. (1972), and for descriptive purposes 
by Fraga (1984). Size of the seeds is 0.5-0.6 $\mathrm{mm}$, and the verrucate sculpture pattern is highlighted by both authors. Our results mainly agree with their description.

Section Pyronium, represented by E. umbellata in the European nucleus, has clear distinct characters. The muticous, exerted anthers, glabrous ovary and pink, urceolate corolla are shared with E. multiflora and the other species of the sect. Gypsocallis, whereas the syninflorescence type with whorls of flowers at the end of secondary branches are closer to E. australis (sect. Tylospora) and other species. Seed morphology has two exclusive characters: the "omega type" surface cells boundaries and a strongly verrucate (micropapillate) secondary sculpture. Both characters should be considered as with a high taxonomic importance as stated by Barthlott (1984). This supports the existence of an exclusive section for this species, although infrageneric classification in this large genus needs a thorough review (Oliver, 2000). Comparisons with the African species of Pyronium will help to clarify it. Because of its original seed morphological type, no relations with other European sections or species can be established from seed morphology of E. umbellata.

ACKNOWLEDGEMENTS. We would like to thank every person and institution that has provided seeds for this study (see table 1). Partially supported by the proyect: CGL200606890, Ministerio de Educación y Ciencia.

\section{BIBLIOGRAPHY}

BARBERO, M., G. BONIN \& P. QUÉZEL -1975Les pelouses écorchées des montagnes Circum-Méditerranèennes Phytocoenologia 1(4): 427-459.

BARTHLOTT, W. -1981- Epidermal and seed surface characters of plants: systematic applicability and some evolutionary aspects Nord. J. of Bot. 1: 345-355.

BARTHLOTT, W. -1984- Microstructural features of seed surface. In HEYWOOD, V. H. \& D. M. MOORE (eds.) Current concepts in Plant Taxonomy. Academic Press, London, pp. 95-105.

BAYER, E. H. -1993- Erica L. In CASTROVIEJO S. et al. (eds.) Flora Iberica 4. C.S.I.C. Madrid, pp. 485-506.

BENITO CEBRIÁN, N. DE -1948- Brezales y brezos. Boletín del Instituto Forestal de Investigaciones y Experiencias 39: 1-67.

BENTHAM, G. -1839- Ericaceae In DE CANDOLLE A. P. (ed.) Prodromus sistematis naturalis regni vegetabilis 7 . Paris, pp. 580733.

BERGGREN, G. -1981-Atlas of seeds vol. 3. Swedish Natural Science Research Council, Stockholm, pp. 259.

BROWICZ, K. -1983- Bruckenthalia Reichnb. In Chorology of trees and shrubs in south-west Asia and adjacent regions vol. 2 p. 9 and 49 (map).

COLMEIRO, M. -1887- Erica L. In COLMEIRO, M. Enumeración y revisión de las plantas de la península hispano-lusitana e islas Baleares vol. 2. Imprenta de la vda. e hija de Fuentenebro, Madrid, pp. 528-538.

DÍAZ, T. E. -1998- Síntesis de la vegetación arbustiva de Europa occidental. I: Brezales (Calluno-Ulicetea). Itinera geobot. 11: 7-31.

FAGÚNDEZ，J. \& J. IZCO -2003- Seed morphology of Erica L. sect. Chlorocodon Bentham. Acta Bot. Gall. 150(4): 401-410.

FAGÚNDEZ, J. \& J. IZCO -2004a- Seed morphology of Calluna Salisb. (Ericaceae). Acta Bot. Malacitana 29: 215-220.

FAGÚNDEZ, J. \& J. IZCO -2004b- Seed morphology of Daboecia D. Don (Ericaceae). Belgian J. of Bot. 137(2): 188-192.

FAGÚNDEZ, J. \& J. IZCO -2008- Seed morphology of Erica L. sect. Loxomeria Salisb. ex Benth., sect. Eremocallis Salisb. ex Benth, sect. Brachycallis I. Hansen (Ericaceae) and its systematic implications. Plant Biosyst. 143 (in press).

FRAGA, M. I. -1984- Valor taxonómico de la morfología de las semillas en las especies del genero Erica presentes en el NO de España. 
Acta Bot. Malacitana 9: 147-152.

HANSEN, I. -1950- Die europäischen Arten der Gattung Erica L. Botanische Jahrbücher 75: $1-81$

HUCKERBY, E., R. MARCHANT \& F, OLDFIELD -1972- Identification of fossil seeds of Erica and Calluna by Scanning Electro Microscopy. New Phytol. 71: 387392.

KRON, K. A., W. S. JUDD, P. F. STEVENS, D. M. CRAYN, A. A. ANDERBERG, P. A. GADEK, C. J. QUINN \& J. L. LUTEYN 2002- Phylogenetic classification of Ericaceae: Molecular and morphological evidence. Bot. Review 68(3): 335-423.

MCGUIRE, A. F. \& K. A. KRON -2005Phylogenetic relationships of European and African ericas. Int. J. of Plant Sci. 166(2): 311-318.

NELSON, E. C. -2007- The original material of two Turkish species of Erica (Ericaceae) described and named by Richard Anthony Salisbury (1761-1829). Turkish J. of Bot. 31: 1-4.

OLIVER, E. G. H. -1989- The Ericoideae and the southern African heathers. Bot. J. of the Linn. Soc. 101: 319-327.

OLIVER, E. G. H. -1996- The position of Bruckenthalia versus Erica. Heather Society Yearbook: 6.

OLIVER, E. G. H. -2000- Systematics of Ericeae (Ericaceae: Ericoideae) species with indehiscent and partially dehiscent fruits. Contributions from the Bolus herbarium 19: 1-483.

PINTO DA SILVA, A. R. \& A. N. TELES -1971Catálogo de plantas herborizadas. Mem. da Soc. Brot. 21: 229.

REICHENBACH, H. G. L. -1831- Bruckenthalia Flora germanica excursoria 1, 3: 413. Leipzig.

SALISBURY, R. A. -1802- Species of Erica. Transactions of the Linnean Society London (Botany) 6: 316-388.

SCHUMANN, D. \& G. KIRSTEN -1992-Ericas of South Africa. Fernwood press, South Africa, pp. 272.

STEVENS, P. F. -1978- Bruckenthalia Reichb. In DAVIS, P. H. (ed.) Flora of Turkey. Vol. 6, pp. 97-98.

WEBB, D. A. \& E. M. RIX -1972- Erica L. In T. G. TUTIN et al. (eds.) Flora Europaea Vol. 3. Cambridge, U.K., pp. 5-8.

WEBB, D. A. -1972- Bruckenthalia Reichenb. In: Tutin, T. G. et al. (eds.) Flora Europaea Vol. 3. Cambridge, U.K., pp. 8

WILLKOMM, H. M. -1870- Erica L. In WILLKOMM, H. M. \& J. M. LANGE (eds.) Prodromus florae hispanicae vol. 2. Stuttgart, pp. 343-348.

WILSON, D. G., R.MARCHANT \& F OLDFIELD -1973- Fossil seeds of Erica from the Cromer forest bed series. New Phytol. 72: 1235-1237. 